\title{
Ahmed valve in refractory glaucoma. Behavior of intraocular pressure at 24 months
}

\section{Válvula de Ahmed en glaucoma refractario. Comportamiento de la presión intraocular a 24 meses}

\author{
Rodolfo Monti' ${ }^{1}$ Evangelina Espósito ${ }^{1}$, María E. Forniés-Paz ${ }^{1}$, Nicolás Crim ${ }^{1}$, Juan A. Dalmagro', \\ Horacio M. Serra ${ }^{2}$ and Julio A. Urrets-Zavalía ${ }^{1 *}$ \\ ${ }^{1}$ Department of Ophthalmology, University Clinic "Reina Fabiola", Catholic University of Córdoba; ${ }^{2}$ CIBICI-CONICET, Faculty of Chemical Sciences, \\ National University of Córdoba. Argentina
}

\begin{abstract}
Objective: To evaluate the results of the Ahmed valve implant in patients with different types of refractory glaucoma. Patients, material and methods: 14 eyes of 13 patients older than 18 years of age with glaucoma refractory to maximum medical treatment and operated by the implantation of an Ahmed valve (Model AGV-FP7) between August 2007 and April 2015, with a minimum follow-up of 24 months, were evaluated retrospectively It was considered absolute success when the postoperative intraocular pressure (IOP) was between 5 and $22 \mathrm{mmHg}$ without medical antiglaucomatous treatment; relative success when the postoperative IOP was within that range, but with the help of one or more antiglaucomatous eye drops; and failure when the postoperative IOP was less than 5 or greater than $22 \mathrm{mmHg}$, or when a valve explant had to be performed. Results: In patients with chronic open-angle glaucoma, $14.29 \%(n=1)$ presented absolute success, $57.14 \%(n=4)$ relative success, and in $28.57 \%(n=2)$ valve surgery failed. In all patients with pseudoexfoliation glaucoma, glaucoma associated with uveitis and congenital glaucoma, a relative success was obtained. Conclusions: The Ahmed valve implant was effective in reducing IOP in refractory glaucoma to medical treatment in a significant number of cases in this series, and relative success was achieved in most of them.
\end{abstract}

Key words: Refractory glaucoma. Complicated glaucoma Secondary glaucoma Ahmed valve. Glaucoma surgery Primary open angle glaucoma.

\section{Resumen}

Objetivo: Evaluar los resultados del implante de válvula de Ahmed en pacientes con diferentes tipos de glaucoma refractario. Pacientes, material y métodos: 14 ojos de 13 pacientes mayores de 18 años con glaucoma refractario al tratamiento médico máximo y operados mediante la implantación de una válvula de Ahmed (Modelo AGV-FP7) entre agosto de 2007 y abril de 2015, con un seguimiento mínimo de 24 meses, fueron evaluados retrospectivamente. Se consideró éxito absoluto cuando la presión intraocular (PIO) postoperatoria se hallaba entre 5 y $22 \mathrm{mmHg}$ sin tratamiento médico antiglaucomatoso; éxito relativo cuando la PIO postoperatoria se hallaba dentro de ese rango, pero con la ayuda de uno o más colirios antiglaucomatosos; y fracaso cuando la PIO postoperatoria era menor de 5 o mayor de $22 \mathrm{mmHg}$, o cuando se debió proceder al explante de la válvula. Resultados: En los pacientes con glaucoma crónico de ángulo abierto, el 14.29\% $(n=1)$ presentó éxito absoluto, el $57.14 \%(n=4)$, éxito relativo, y en el $28.57 \%(n=2)$ la cirugía valvular fracasó. En todos los pacientes

Correspondence:

*Julio A. Urrets-Zavalía

E-mail: julioaurrets@gmail.com
Available online: 07-05-2018

Date of reception: 02-17-2017

Date of acceptance: 08-24-2017 DOI: 10.24875/RMOE.M18000006
Rev Mex Oftalmol (Eng). 2018;92(2):80-86 www.rmo.com.mx 2604-1731/@ 2017 Sociedad Mexicana de Oftalmología. Published by Permanyer México SA de CV. This is an Open Access article under the CC BY-NC-ND license (http://creativecommons.org/licenses/by-nc-nd/4.0/). 
con glaucoma pseudoexfoliativo, glaucoma asociado a uveítis y en glaucoma congénito se obtuvo un éxito relativo. Conclusiones: El implante valvular de Ahmed fue eficaz para reducir la PIO en glaucomas refractarios al tratamiento médico en un número importante de casos en esta serie, y se llegó a un éxito relativo en la mayoría de ellos.

Palabras clave: Glaucoma refractario. Glaucoma complicado. Glaucoma secundario. Válvula de Ahmed. Cirugía de glaucoma. Glaucoma primario de ángulo abierto.

\section{Introduction}

Refractory glaucoma is any type of glaucoma that has not responded to maximum medical treatment after the failure of one or more surgical interventions for glaucoma ${ }^{1}$. The management of refractory glaucoma is a difficult task for any glaucoma surgeon. Various drainage devices have been used in the treatment of refractory glaucoma in adults and children, especially when filtering surgery has failed or is anticipated to have a high risk of failure ${ }^{2-6}$.

The Ahmed valve, as its name suggests, is a device for draining the aqueous humor, composed of a siliconized reservoir of elliptical shape that is implanted under the conjunctiva in the equatorial area of the eyeball, and a silicone tube whose anterior end is housed in the anterior chamber. There are several models that vary in size and design. Its objective is the reduction of intraocular pressure (IOP) through the exit of the aqueous humor through the connection tube and its reabsorption in the filtering bleb that forms around the reservoir?.

The objective of this study is to evaluate the results of Ahmed valve implantation in patients with refractory glaucoma.

\section{Patients, material and methods}

We retrospectively evaluated 14 eyes of 13 glaucoma patients refractory to maximum medical treatment who underwent Ahmed valve implantation consecutively between August 2007 and April 2015, with a minimum follow-up of 24 months (Table 1). The same surgeon (JAD) performed all surgeries. An Ahmed valve model AGV-FP7 (New World Medical, Rancho Cucamonga, CA, USA) was used, consisting on a silicone body or plate of elliptical shape (13-mm width and 16-mm length) and a total area of $184 \mathrm{~mm}^{2}$, which is implanted under the conjunctiva in the equatorial zone of the eyeball and inside which is housed a trapezoidal chamber that generates a Venturi effect that facilitates the circulation of aqueous humor, and a silicone tube of $25 \mathrm{~mm}$ in length, with an external diameter of $0.63 \mathrm{~mm}$ and an internal diameter of $0.30 \mathrm{~mm}$.
The data evaluated were the age at the time of surgery, the clinical form of glaucoma, the mean pre and postoperative IOP, the average follow-up in months, the need for topical medication for glaucoma after surgery and the occurrence of complications after surgery. The IOP was evaluated in all patients with a Goldmann applanation tonometer. Postoperative IOP was evaluated at the first week, at 1 month, and at 6, 12 and 24 months.

\section{Surgical technique}

After the preparation of the surgical field with $10 \%$ iodopovidone, peribulbar anesthesia with $2 \%$ lidocaine and fixation of the eyeball by traction of the rectus, or by means of corneal traction points, a conjunctival flap is made with its base in the fornix. Tenon's conjunctiva and capsule are widely dissected to expose the superior temporal quadrant where the reservoir will then be sutured. The reservoir is placed between the muscles and below the Tenon's capsule, rotating it later in the horizontal plane to place it correctly with the connecting tube facing the anterior part of the eyeball. The reservoir is sutured to the sclera about $8-10 \mathrm{~mm}$ from the limbus, using non-absorbable nylon $5 / 0$ to $8 / 0$ sutures. The entrance tunnel for the tube is made $4 \mathrm{~mm}$ from the sclerocorneal limbus, by puncturing the sclera with a $23 \mathrm{G}$ gauge needle and then the tube is introduced into the anterior chamber, placing it in a plane parallel to the iris, halfway between the iris and the cornea, always avoiding the friction of the tube with the corneal endothelium. Finally, the conjunctiva is closed with absorbable Vicryl 8/0 sutures. After surgery, an ointment with dexamethasone and a broad-spectrum antibiotic is placed in the lower conjunctival cul-de-sac and the eye is occluded for 24 hours.

The absolute success of the surgery was considered when the postoperative IOP was between 5 and $22 \mathrm{mmHg}$ without medical antiglaucomatous treatment; relative success when the postoperative IOP was within that range, but with the aid of one or more antiglaucomatous eye drops; and failure when the postoperative IOP was less than 5 or greater than $22 \mathrm{mmHg}$, or when a valve explant had to be performed. 


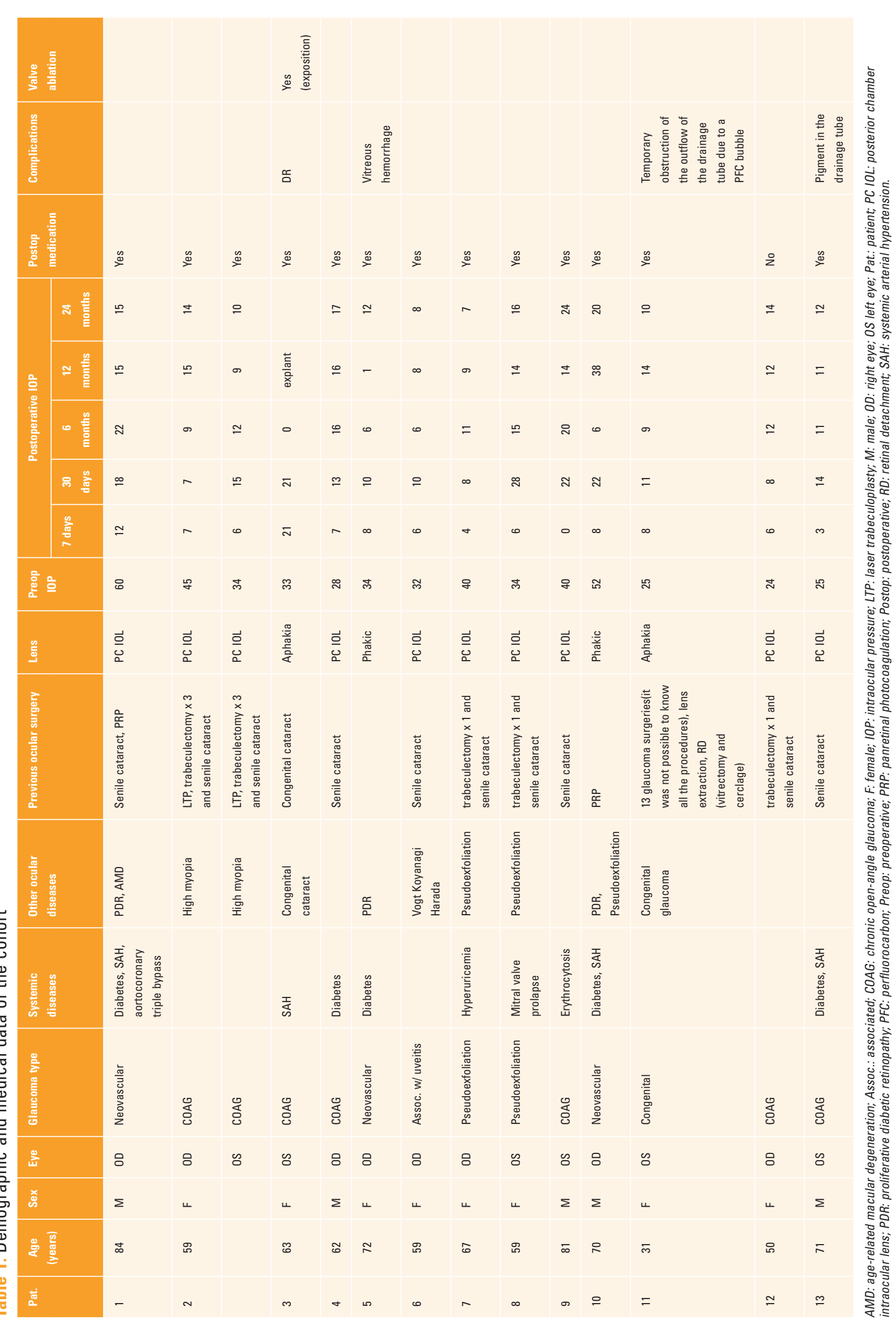


The Institutional Committee of Ethics of Health Research of our institution approved the present study.

\section{Statistical methods}

Descriptive and frequency statistics were used for the variables of age, sex and type of glaucoma. For analytical statistics, preoperative and postoperative IOP measurements were compared using the Friedman test. The analysis of normality of the variables was performed using the Shapiro-Wilks test. The Wilcoxon signed rank test was used to compare changes in the number of eye medications. Statistical significance was considered when $p<0.05$.

\section{Results}

The mean age of the patients was $63 \pm 13$ years, range $=31-84$ years. Sixty-two percent of the patients were women. The clinical forms of glaucoma were: 6 (7 eyes) patients with chronic open-angle glaucoma (COAG) (50\%), 3 (3 eyes) with neovascular glaucoma (21.4\%), 2 (2 eyes) with pseudoexfoliation glaucoma (14.3\%), 1 (1 eye) with glaucoma associated with uveitis $(7.1 \%)$ and 1 ( 1 eye) with congenital glaucoma (already operated on multiple occasions) $(7.1 \%)$ (Table 1$)$. The mean preoperative IOP was $36.14 \pm 10.49$, range $=24-60 \mathrm{mmHg}$. After surgery, a significant and sustained decrease in IOP was observed during the 24 months of minimal follow-up (Fig. 1). The IOP presented a non-normal distribution (Shapiro-Wilks test). The mean postoperative IOP at the first week was $7.29 \pm 4.81$, range $=0-21 ; p<0.0001$; at 1 month, $14.79 \pm 6.47$, range $=7-28 ; p=0.0087$; at 6 months, $11.07 \pm 5.88$, range $=0-22 ; p<0.0001$; at 12 months, $13.54 \pm 8.40$, range $=1-38 ; p=0.0002$; and at 24 months, $13.77 \pm 4.78 \mathrm{mmHg}$, range $=7-24$; $p=0.0043$ (Fig. 2 and Table 2). The average follow-up was 30 months, range $=24-54$ months. At 24 months after surgery, $7.14 \%$ of the patients presented an absolute success, $78.57 \%$ a relative success, and $14.29 \%$ showed treatment failure (Table 2). Only one patient required explant of the valve due to exposure 12 months postoperatively.

According to the preoperative clinical form of glauco$\mathrm{ma}$, in the COAG, $14.29 \%$ presented absolute success, $57.14 \%$, relative success, and $28.57 \%$, failure. In patients with pseudoexfoliation glaucoma, glaucoma associated with uveitis and congenital glaucoma, 100\% presented relative success (Fig. 3). The average number of preoperative topical medications was $2.85 \pm 0.8$, range $=3-5$, and at 24 months postoperatively, $2.64 \pm 0.93$, range $=0-5 ; p=0.7451$.

In the postoperative period, a hypertensive phase was recorded in $70 \%$ of the cases. It was necessary to begin hypotensive medication at the second week in $39 \%(n=5)$ of the cases, followed by the sixth week in $31 \%(n=4)$ of the cases.

In none of the cases, local antimetabolites were used as adjuvants. In patient 10 with neovascular glaucoma secondary to proliferative photocoagulated diabetic retinopathy, intravitreal injection of $1.25 \mathrm{mg} / 0.05 \mathrm{~mL}$ of bevacizumab (Avastin $\AA$, Roche Diagnostic $\mathrm{GmbH}$, Manheim, Germany) was performed 7 days before valve surgery to control the active neovascularization of the iris and the iridocorneal angle.

\section{Discussion}

In recent years, therapeutic alternatives have been developed for patients with glaucoma refractory to conventional treatment, such as treatment with antimetabolites in trabeculectomy and different cyclodestructive procedures. These alternatives fail to control IOP in all patients, and put the patient at risk of developing potentially serious complications such as dry eye, corneal ulcers, endothelial decompensation, hyphema, iritis, pupillary block, choroidal detachment and hypotonia ${ }^{8}$.

Valvular implants for glaucoma have grown in popularity in recent years, and this is due to an improvement in the type of implants available and a better knowledge about their management. Currently we have valved (Ahmed) and nonvalved implants (Molteno, Baerveldt). The reported success rates are $90 \%$ in most types of glaucoma, even those with a poor prognosis, such as neovascular and uveitic ${ }^{8}$. Our work presents the results we obtained after the Ahmed valve implant in patients with refractory glaucoma. The Ahmed valve was selected because it avoids serious postoperative hypotonia since it has a safer profile, ${ }^{9}$ although other groups have reported better results with the Baerveldt model ${ }^{10}$.

The results of this investigation show that the device was effective and safe to reduce IOP in the treatment of refractory glaucoma, agreeing with other studies that show a significant reduction in IOP5,7,11,12. In this series of patients, there was only one postoperative complication, related to blunt ocular trauma that caused the exposure of the drainage device. Possibly, in the longterm follow-up of these patients, other complications related to the valve may occur.

According to Yang and Park ${ }^{13}$, the overall surgical success was of approximately $81 \%$ in their heterogeneous 


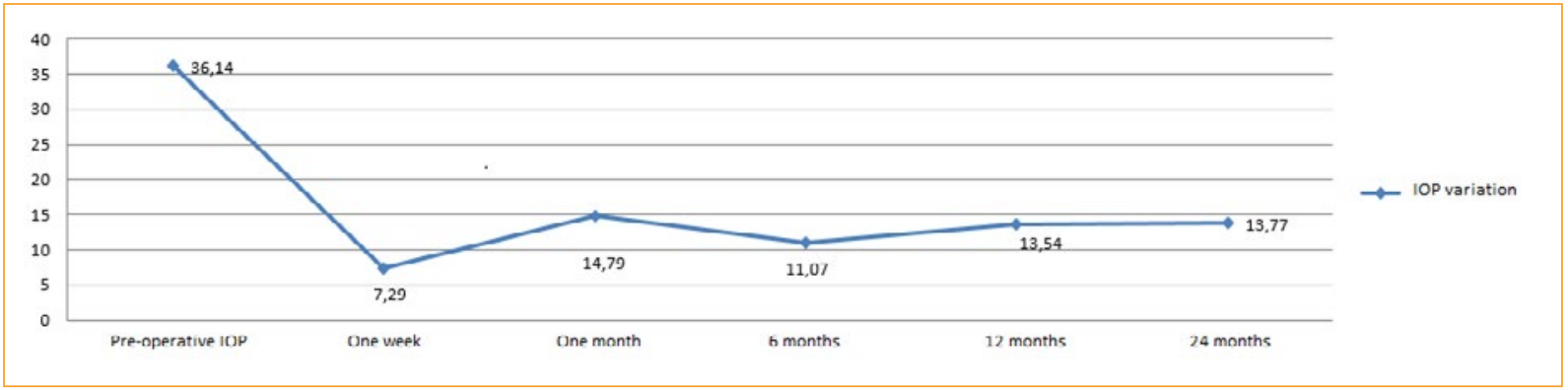

Figure 1. Graph showing the postoperative reduction of IOP and its maintenance during a minimum follow-up of 24 months. IOP: intraocular pressure.

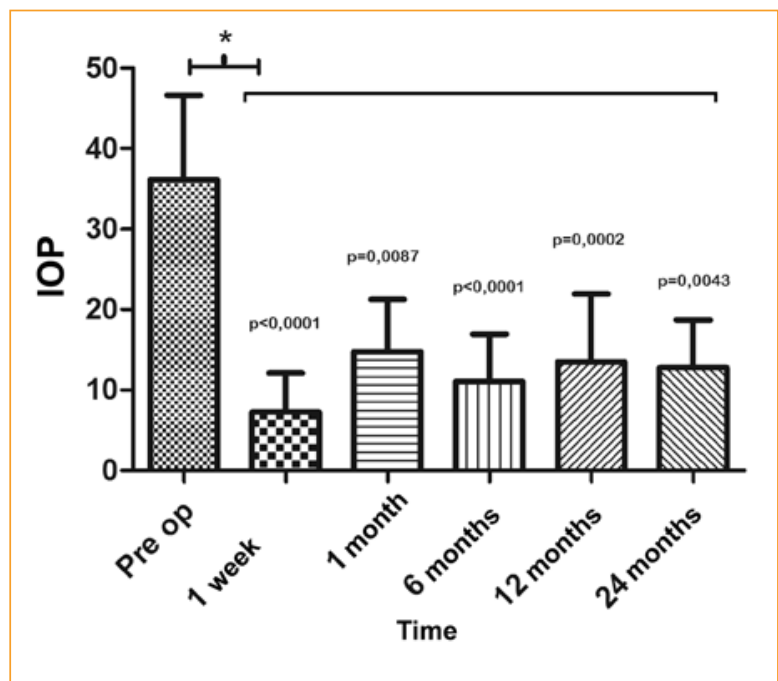

Figure 2. Graph in which the IOP variation can be observed comparatively throughout a minimum postoperative follow-up of 24 months. IOP: intraocular pressure.

group of patients, similar to the results of other implant studies, although the number of patients, success criteria and length of follow-up show a wide variation ${ }^{13}$. These inter-study differences make it difficult to accurately compare the success ratios between the various implant reports. These differences could result from the variety of patients with different ocular pathologies, ophthalmological surgical procedures prior to implantation, different ages at the time of implantation, aphakia and circumstances related to the surgical technique. Valvular implant surgery requires that the surgeon is familiar with the surgical technique and with the close postoperative follow-up in order to avoid or control possible complications, such as perivalvular fibrosis, and thus achieve the correct functioning of the valve for a long period. Generally, the early postsurgical complications described include hypotonia, lower anterior chamber, hyphema, transient increase in IOP and tube occlusion, while longterm complications include encapsulation, altered intracameral tube position, endothelial decompensation, and endophthalmitis 7,14 .

In the study by Coleman, et al. ${ }^{11}$, in which the clinical evolution of 68 eyes subjected to the Ahmed valve placement was prospectively evaluated, a cumulative probability of success at 12 months of $78 \%$ was reported, in agreement with the percentage of total success at 12 months (78.57\%) observed in our series. This is also comparable to the iStent $\AA$ device, which in vitro has been shown to improve the ease of drainage of aqueous humor in $84 \%$ of cases $^{12}$.

The presence of a hypertensive phase after surgery is defined as an IOP greater than $21 \mathrm{mmHg}$ during the first 3 postoperative months. The results allow us to affirm that in this cohort, after surgery, there was a hypertensive stage at the second and sixth week, respectively, which coincides with what is described in the literature. This is comparable to previous studies that showed a hypertensive phase in 25 to $82 \%$ after implantation ${ }^{15,16}$.

In a study published by Parihar, et al., the clinical forms found were late-onset juvenile glaucoma in 6 cases, post-traumatic glaucoma in 12 cases, postoperative secondary glaucoma in 8 cases, closed-angle refractory glaucoma in 15 cases, and open angle refractory glaucoma in 11 cases, and total success was achieved in 46 eyes $(88 \%)^{17}$. In our series, the success obtained was $85.7 \%$ of the cases.

Although our initial experience in this series is encouraging in the long term, the limitation of the study lies in the limited number of patients and the heterogeneity of the clinical forms analyzed. Publications in Spanish language indexed on the subject are scarce, so we 
Table 2: Postoperative results after Ahmed valve implantation in patients with refractory glaucoma.

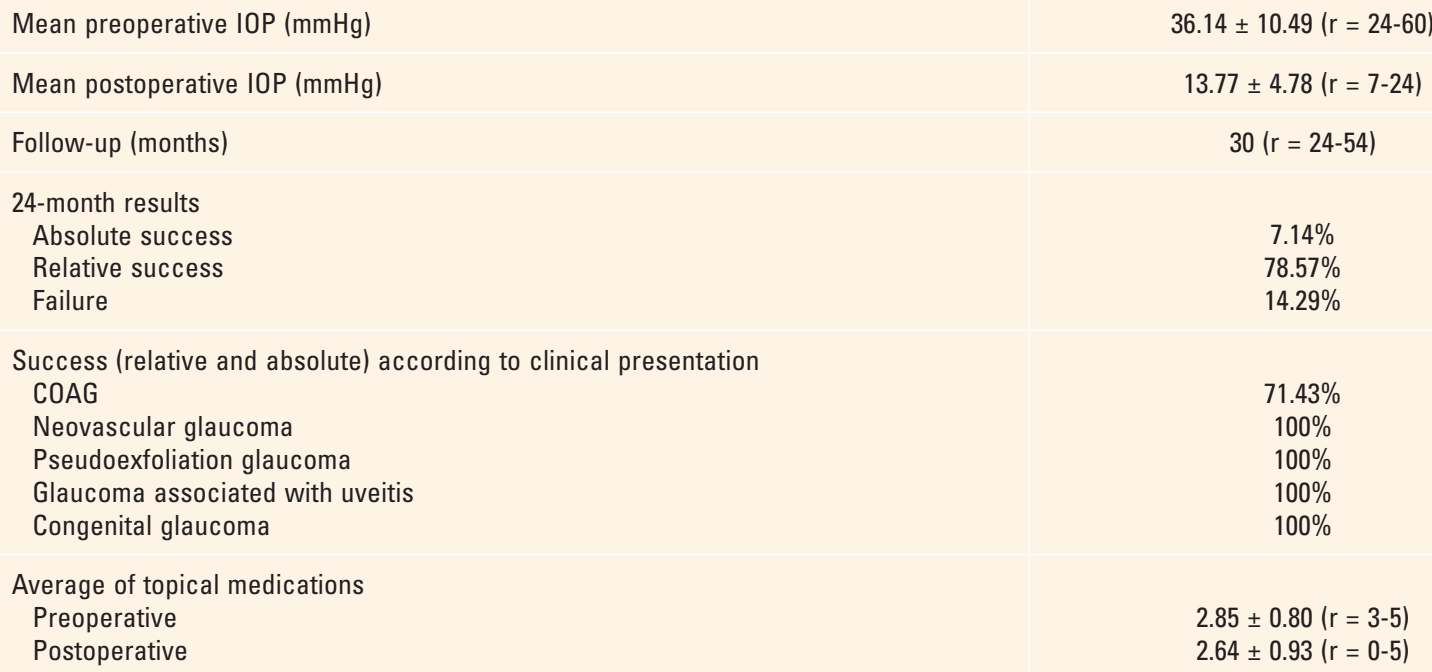

COAG: chronic open-angle glaucoma, IOP: intraocular pressure

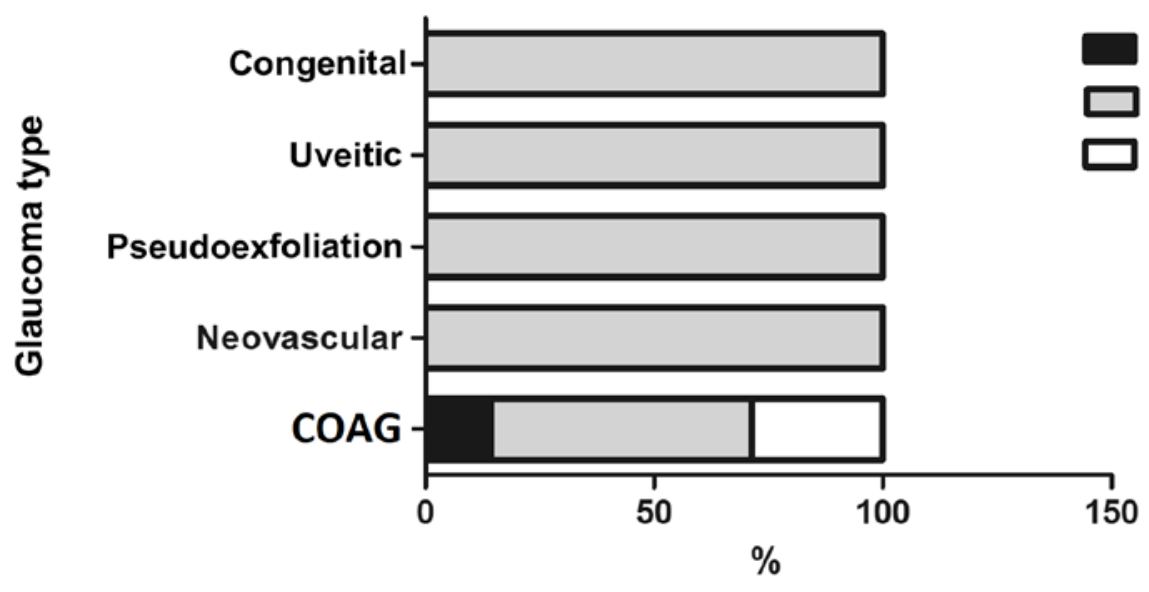

Absolute success

Relative success

Failure

Figure 3. Graph showing the percentage of success in each group according to the type of glaucoma. COAG: chronic open-angle glaucoma; IOP: intraocular pressure.

believe that our work could be useful for the large Spanish-speaking ophthalmology community.

In conclusion, Ahmed's valve implant was effective in reducing IOP in glaucoma refractory to medical treatment in a significant number of cases in this series, reaching relative success in most of them.

\section{Ethical responsibilities}

Protection of human and animal subjects. The authors declare that no experiments were performed on humans or animals for this study.
Confidentiality of data. The authors declare that no patient data appear in this article.

Right to privacy and informed consent. The authors have obtained the written informed consent of the patients or subjects mentioned in the article. The corresponding author is in possession of this document.

\section{Funding}

The authors declare that they have no economic interest in the products mentioned in the present work, 
nor have they received financial assistance for the realization of the same.

\section{Conflict of interest}

There is no conflict of interest of the researchers in this study.

\section{References}

1. Valtot F. Actualités sur les glaucomes réfractaires. J Fr Ophtalmol 2003;26:56-61.

2. Topouzis F, Coleman AL, Choplin N, Bethlem MM, Hill R, Yu F, et al. Follow-up of the original cohort with the Ahmed glaucoma valve implant. Am J Ophthalmol. 1999;128:198-4.

3. Lai J, Poon A, Chua J, Tham C, Leung A, Lam D. Efficacy and safety of the Ahmed glaucoma valve implant in Chinese eyes with complicated glaucoma. Br J Ophthalmol. 2000;84:718-21.

4. Netland PA, Walton DS. Glaucoma drainage implants in pediatric patients. Ophthalmic Surg. 1993;24:723-9.

5. Colás-Tomás T, Gutiérrez-Díaz E, Tejeda-Palacios P, Barceló-Mendiguchía A, Mencía-Gutiérrez E. Resultados a medio plazo de dispositivos de drenaje para glaucoma en pacientes pediátricos. Arch Soc Esp Oftalmol. 2012;87:38-43.

6. Lee HY, Park JS, Choy YJ, Lee HJ. Surgical outcomes of different Ahmed Glaucoma Valve implantation methods between scleral graft and scleral flap. Korean J Ophthalmol. 2011;25:317-22.
7. Gutiérrez-Díaz E Montero-Rodríguez M. Dispositivos de drenaje para glaucoma. Madrid: Ergon; 2002. p. 119-27.

8. Diaz-Llopis M, Salom D, García-Delpech S, Udaondo P, Millan JM, Arevalo JF. Efficacy and safety of the pars plana clip in the Ahmed valve device inserted via the pars plana in patients with refractory glaucoma. Clin Ophtalmol. 2010;4:411-16.

9. Budenz DL, Feuer WJ, Barton K, Schiffman J, Costa VP, Godfrey DG, et al. Postoperative complications in the Ahmed Baerveldt Comparison Study during five years of follow-up. Am J Ophthalmol. 2016;163:75-82.

10. Christakis PG, Kalenak JW, Tsai JC, Zurakowski D, Kammer JA, Harasymowycz PJ, et al. The Ahmed Versus Baerveldt Study: five-year treatment outcomes. Ophthalmology. 2016;123:2093-102.

11. Coleman AL, Hill R, Wilson MR, Choplin N, Kotas-Neumann R, Tam M, et al. Initial clinical experience with the Ahmed Glaucoma Valve Implant. Am J Ophthalmol. 1995;120:23-31.

12. Bahler CK, Smedley GT, Zhou J, Johnson DH. Trabecular bypass stents decrease intraocular pressure in cultured human anterior segments. Am J Ophthalmol. 2004;138:988-94.

13. Yang HK, Park KH. Clinical outcomes after Ahmed valve implantation in refractory paediatric glaucoma. Eye. 2009;23:1427-35.

14. Zarei R, Amini H, Daneshvar R, Nabi FN, Moghimi S, Fakhraee G, et al. Long-term Outcomes of Ahmed Glaucoma Valve Implantation in Refractory Glaucoma at Farabi Eye Hospital, Tehran, Iran. Middle East Afr J Ophthalmol. 2016;23:104-9.

15. Nouri-Mahdavi K, Caprioli J. Evaluation of the hypertensive phase after insertion of the Ahmed glaucoma valve. Am J Ophthalmol. 2003; 136:1001-8.

16. Chen TC, Bhatia LS, Walton DS. Ahmed valve surgery for refractory pediatric glaucoma: a report of 52 eyes. J Pediatr Ophthalmol Strabismus. 2005;42:274-83.

17. Parihar JKS, Vats DP, Maggon R, Mathur V, Singh A, Mishra SK. The efficacy of Ahmed glaucoma valve drainage devices in cases of adult refractory glaucoma in Indian eyes. Indian J Ophthalmol. 2009;57:345-50. 